\title{
Harmonization of legislation: Reviewing the laws of government administration
}

\author{
Lily Evelina Sitorus, Anna Erliyana and Yunus Husein \\ Ministry of Law and Human Rights \\ li15779@gmail.com
}

\begin{abstract}
Harmonization of legislation is an important process in the rule of law. A good law is a law that complies with applicable principles and norms. This paper will discuss three interrelated legislation. First, the Law on State Administrative Courts that serves to provide justice for the parties due to arbitrary state administrative decisions. Second, the Law on Administration of Government governing the actions of state administrators to comply with applicable law and three, Laws on the Prevention and Handling of Crisis Financial System which is the protocol handling financial system crisis. One of the findings in this paper is the discretion that should be the freedom of administrative officials in making decisions in accordance with their authority to be limited when the element of approval is a compulsory norm. In fact, the crisis often requires speed in making decisions.
\end{abstract}

Keywords: harmonization, legislation, discretion, administrative law, financial crisis

\section{Introduction}

In an effort to find the best solution for government policy to overcome the financial system crisis, the various laws used as a reference comparison by doing interpretation either through the articles or judges' consideration related to the use of the Act in its verdict. The role of harmonization of legislation is important because different interpretations often occur for multidimensional cases such as Century Bank bailout policy. The selection of systematic and historical interpretations in this paper is also inseparable from an effort to harmonize the regulation.

The process of forming the Law in the reform era involves the government, House of Representatives (DPR) and the community. It is basically an ideal form in the process of forming a participatory law in order to create responsive laws (Saifudin, 2006). Representative agencies are unlikely to capture the widespread aspirations of society. Therefore, the representative institution should open the public access to participate in the process of forming the Act. This is because it is not easy to make laws that are fully responsive given the plurality of social conditions of society and the different backgrounds of the various political forces in society.

\section{Literature review}

Reviewing of legislation in the Indonesian state administration has been started since 1970 through Law No. 14 year 1970 on the Principles of Judicial Power, and further stipulated in the 1945 Constitution of the third amendment, a process to resolve normative conflicts through legal mechanisms. Examining of legislation as normative control whose authority is given to judicial authority institution, intended to maintain consistency and vertical harmonization in order to maintain legal order and legal certainty as well as between legal norms in various forms of legislation so that they can explain each other (Hoesein, 2006). 
Object of the testing of legislation is any form of regulation that regulates (regeling) and binding in general. In the perspective of the types and rules of legislation as stipulated in Temporary People's Consultative Assembly (MPRS) Decree No. XX / MPRS / 1966, Decree of MPR No III / MPR / 2000 and Law No. 10 Year 2004 and Law No. 12 of 2011, then the object of testing of legislation in hierarchical order is Law / PERPU, PP, Perpres, and Perda at both Provincial and Regency / Municipality levels. However, due to the limitation of the object of testing of legislation, the object of the regulation that can be tested by the Supreme Court is limited to the PP, Perpres and Perda at both the Provincial and Regency / Municipality levels.

According to Hoesein (2006), the limitation of the object of judicial review of laws only to the statutory laws, is because the jurisdiction of the 1945 Constitution (before amendment) does not recognize and does not regulate the examination of the laws. The system of law which acknowledge the distribution of power tend to leads to 'The supremacy of parliament.' Therefore, it is not possible that the legal products of the People's Legislative Assembly and the President in the form of laws are examined by the Supreme Court whose status is equal and that the right to test in a hierarchical manner is place upon the MPR or at least by the author himself. Legal products under the law as a product of state administrative bodies / officials which function as the implementation of the law is still possible to be tested by the Supreme Court based on the principle of supervision or normative control.

In the context of law enforcement on governance, the Law No. 30 Year 2014 becomes the new basis for the state administrative court in examining state administrative disputes. Law No. 30 Year 2014 will also make it easier for judges in the Administrative Court to examine an administrative dispute as it may become a material legal source in a judicial decree of state administration. So far Law No. 5 Year 1986 on the State Administrative Court as amended by Law No. 9 Year 2004 and Law No. 51 Year 2009 only regulate the procedural law in case of dispute between civilian person or legal entity with state administration officials (Mawardi, 2015).

In practice, judges often face difficulties when faced with cases whose material laws are not regulated in the Law of Administrative Court so to overcome that the judges based their opinions on experts (doctrine) or jurisprudence. One of the elements set forth in the Law No 30 Year 2014 is related to decisions issued by government administration officials. The formal objectives and products of a governmental administration procedure are administrative decisions containing the provisions of the rights and obligations of individuals or other members of the public in a public administration. Construction of the definition of State administrative decisions (KTUN) has changed significantly after the enactment of Law No. 30 of 2014 which expands the meaning of KTUN.

According to Mawardi (2015), the factual action as part of the KTUN as the object of the lawsuit in the TUN dispute is an inseparable part of the discretionary provisions set forth in article 22 to article 32 of the Law No 30 Year 2014. Article 1 Paragraph 9 of the Law No 30 Year 2014 describes discretion as a decision and / or action determined and / or performed by a government official to address the concrete issues faced in the administration of government in terms of laws that provide choice, not regulate, incomplete or unclear And / or government stagnation. Further discretionary use is provided in Article 31 where special use of discretion which confuses authority may then be canceled. 
The meaning of confusing authority is to use Discretion not in accordance with the purpose of the Authority granted, not in accordance with the provisions of Articles 26, 27 and 28; And / or contrary to The general principle of good governance (AUPB). It is in this context of discontinuation of discretion that the Administrative Court is authorized to examine, test, hear and decide. However, if using the criterion KTUN version of Law No. 51 of 2009, the scope of authority (intra vires) of state administrative courts at this time is only limited to testing the state administrative decisions (beschikking), but with the provisions of article 87 of the Law No 30 Year 2014, the factual act which is often the act of unlawful by the government (onrechtmatige overheidsdaad / OOD) legally becomes the authority of administrative Court (PTUN) to examine and prosecute.

Discretion is generally defined as the power to make decisions that can not be determined truthfully or wrongly objectively. Lord Diplock states the following: "The very concept of administrative discretion involves a right to choose between more than one possible course of action upon which there is room for reasonable people to hold differing opinions as to which is to be preferred." So, it can be it is said that discretion lies in the choice of inherent right in the act of state administration (Grey, 1979). Administrative discretion involves almost every aspect of public administration. Discretion also provides a great dilemma, as it is considered important but problematic. In fact, despite the many political influences that attempt to control discretion, administrative organs often use discretion in relation to officials and courts. In addition, the government also uses discretionary policies related to mandates and bureaucratic rules. Today, the perception of discretion involves solving social problems, the dominant political climate and the role of information-based Internet technology (Holzer and Yang, 2005).

\section{Discussion}

The model of Century Bank's bailout policy which is a Stability committees of the financial system (KSSK) decision can also be tested with the Law No 9 Year 2016 on Prevention and handling of the financial system crisis (PPKSK) if it is categorized as State administrative decisions (KTUN). Based on Article 49 of the PPKSK Law, the decision established by the KSSK and / or implementation of the decision by each member of the KSSK is valid and binding on the parties. The formulation of the article is in accordance with the formulation of KTUN existing in the Administrative Court Law. Therefore, the settlement is the competence of the state administrative court. If it is proven in the State Administrative Court that there is an element of abuse of authority, then the subsequent follow-up may be through other courts such as civil and criminal.

The controversy of Century Bank's bailout policy was also adopted in the Law on PPKSK so that the handling of the financial system crisis no longer used the bailout policy, but with the concept of bail-in. According to the Minister of Finance, the concept of bail-in is the handling of problems using the bank's own resources and banking contributions. This is because strong coordination among agencies in the prevention and handling of financial system crises is absolutely necessary for the financial system to function effectively and efficiently, "The PPKSK Act focuses on crisis prevention efforts, especially through the stricter regulation and supervision of systemic banks" (Tempo, 2017).

The most important difference with the PPKSK Act is the status of the KSSK decision. If previously in Government regulation in lieu of law (PERPU) No 4 Year 2008 on Financial 
system safety net (JPSK), KSSK has no obligation to get approval from President when deciding Century Bank bailout policy, then with the PPKSK Act, Presidential approval becomes an important point. That is because the decision of KSSK is only a recommendation to the President to determine the crisis situation so that the decision of KSSK can not stand alone as a KTUN. This can be a problem in itself when testing the decision of handling the crisis into the competence of PTUN.

In addition to Article 49, Article 48 of the PPKSK Law also regulates the competence of KSSK resolution which indicates the abuse of authority as the competence of PTUN. However, if the KSSK decision in question still requires the approval of the President, then the KSSK decision can not be tested as a KTUN, it is because the decision of the President after obtaining the KSSK recommendation is final and binding, then the President's decision becomes the object of the lawsuit on PTUN.

Law No. 48 Year 2009 on Judicial Power, Article 20 paragraph (2) letter b explains that the Supreme Court is authorized to examine the laws and regulations under the Act on the Law. This can be interpreted if the discretion can not be tested by the State Administrative Court related to the approval element then the discretion should be tested by the Supreme Court. In the context of Century Bank's bailout policy based on PERPU JPSK, approval is not required so that the policy can be tested by PTUN. However, in its development with the Law No. 30 of 2014 which specifically regulates the discretion of the government, the model of Bank Century bailout policy can be used as a policy of financial crisis.

The presence of Law No. 9 Year 2016 on PPKSK can be a solution for the policy of handling the financial system crisis in the future. However, the accountability of decision makers in the PPKSK Law is also worth considering so it does not become controversial such as Century Bank bailout policy. Therefore, the protocol policy of handling the financial system crisis in the future is expected to have a strong legal basis. The consideration of this paper by proposing revisions related to discretion because the core of the discretion itself is freedom so that when discretion is limited by the element of approval then the discretion becomes meaningless. Another reason why Article 25 Paragraph (1) Law No. 30 Year 2014 on Administration of Government needs to be revised is to harmonize with Law No. 5 Year 1986 jo Law No. 9 Year 2004 jo Law No. 51 Year 2009 on PTUN. The discretion which has become the norm in Article 25 paragraph (1) is directly accountable to the authority of the Administrative Court, therefore, the requirements of the superior's approval should not be necessary.

\section{Lesson learned}

The presence of Law No. 30 Year 2014 on Government Administration (AP Act) makes the government can no longer base its actions on PERPU in terms of discretion. That's because discretion has been specially regulated in the Act. The important element of force which generally becomes imperative element in PERPU can no longer be used as legal basis because discretion in AP Law can replace it. However, an approval clause involving discretion regarding the use of state finances may hinder the accountability of government policies. In fact, the pattern of the crisis of the financial system is very fast and requires urgent decisions and the timeconstraint becomes less effective if it depends on the approval in question.

In such situations, discretion testing may be performed by Supreme Court (MA). Decisions concerning the invalidity of legislation as a result of testing may be taken either in relation to the 
examination at the appellate level or on the basis of an application directly to the Supreme Court as provided in Article 20 paragraph (3) of Law No. 48 Year 2009 on Judicial Power. Elucidation of the Article states that the right of the test may be made either to the content of the content of paragraphs, clauses and / or parts of the higher legislation or to the formulation of legislation.

Therefore, harmonization of legislation related to government policy, either in the form of discretion or state administrative decision is still required. This is because the AP Law only regulates the competence of dispute resolution through PTUN so it is necessary to harmonize between AP Law, PTUN Act and UU PPKSK for legal certainty. The importance of harmonization due to the construction of normative rationale is based on legislation. This approach is known as a positivism, the law is nothing but a written rule and the judge is merely a mouthpiece of the law. In its development, the reality is that the law is often left behind on events that occur in society. The lagging of the law can actually be covered with a judge's ruling which can be a jurisprudence in line with the development of jurisprudence.

However, in a country of adherence to the civil law system, a judge is not allowed to undertake the discovery of a new law unless it is governed by applicable law. The function of the judge is only implementing the existing provisions. This is different in a common law state, allowing judges to even become a necessity for setting a precedent if a case is found to have no rules. The judge's wisdom in making this jurisprudence is then known in Indonesia as the application of progressive law.

Progressive law was first introduced by Satjipto Rahardjo which is a legal concept that is not confined to the concept of the text of the Act alone, but also concerns the sense of justice living in society. In practice, the application of progressive law can be seen from several decisions of the Indonesian Constitutional Court for example in the Corruption Eradication Commission (KPK) Law review, the Court ordered to listen to the record against the criminalization of two leaders of the KPK (Mahkamah Konstitusi, 2010).

These developments seemed to reinforce the statement from Mahfud MD on Mahkamah Konstitusi (2010), that is the Constitutional Court currently embraces progressive law. The Court is not just a judicial or a mouthpiece of a law. The way judges interpret a rule of law generally uses two interpretative patterns of original intent and non-original intent, commonly referred to as textual meaning and contextual meaning. The point of these two patterns is the debate between the adherents of legal positivism with progressive law.

Progressive legal theory can be used as a reference for subsequent research that enables the completion of an increasingly progressive financial system crisis as well. However, it should be understood that the presence of progressive law can not be separated from the responsive law as proposed by Nonet and Selznick which divide the three types of law (Nonet and Selznick, 1978):

a. Repressive Law: Aims to create order, legitimacy leads to social resilience and state objectives, rigid and weak rules for law-makers, subordinate law to power politics and exclusively for society to participate, so that criticism of government is considered defiance. The indication of this type is the passive and opportunistic adaptation of legal institutions to the social and political environment.

b. Autonomous Law: Aims to strengthen legitimacy, procedural justice, complex and binding rules of rulers or society, separation of powers, access restricted by standard procedures, resulting in criticism of the law. Indications of this type are opposing reactions to openness, 
maintaining institutional integrity by legal means of isolating themselves, their responsibilities and accepting a blind formalism in order to achieve an integrity.

c. Responsive Law: Aims to create competencies, subordinate rules of principles and policies, integrated between law and politics, widespread access through integration of legal and social advocacy. This latter type seeks to overcome the tensions of the two previous types, which are more open or adaptive, adapt responsibly and notice the existence of new forces within their environment, criticize established practices and pave the way for change.

The progressive mindset proposed in this paper is also related to the application of a mixed legal system between civil law and common law. The application of the law changes from time to time. The dichotomy of the legal system in the development of increasingly global civilization is very difficult to distinguish. At the level of practice, which developed in various countries is mixed system. Indonesia itself is heavily influenced by the Continental European legal tradition, but the existence of the customary legal system and Islamic legal system also shows the mixing of various legal systems.

The development of law in Indonesia also began to be contaminated with the Anglo Saxon legal tradition. The hypothesis can be seen from various application of rules in the field of business law, class action law suit model, citizen law suit, model of legal reasoning that produces judge made law, until the emergence of dispute resolution institutions that are similar to the tribunal format. Therefore, the use of mixed systems is used in this paper because the policy of Century Bank bailout is a policy that can not be solved by choosing one of the legal system only.

In the previous analysis it has been explained that the legal positivism used in this paper is not a positivism that is rigidly understood by the followers of the progressive law. Hans Kelsen, a lawyer whose influence is widely felt in Indonesia, defines the positivity of law as the system of norms called legal order which is a dynamic form of system. In addition, kelsen also argues that law is always positive and its positivity lies in the fact that it is created and annulled by acts of human beings, thus being independent of morality and similar norms systems. This is according to Kelsen who distinguishes between positive law and natural law (Kelsen, 1961).

Hans Kelsen was also a reformer, because of his modern thinking at the time. According to Kelsen (1961), a theory of law must deal with law as actualy laid down, not as it ought to be. A theory of law must be distiguished from the law itself. A theory of law should be uniform, it should be applicable at all times and in all places. A theory of law must be free from ethics, politics, sociology, history, it must be in other words, be pure. In practice, the pure theory of law is also contradictory because it is considered unable to answer all the existing legal issues in society. The law according to pure legal view lies in the das sollen category rather than on the das sein category (social reality). The person obeys the law because he ought to be obligated to obey it as a will of the state. The question of whether people are in fact obeying or not is outside the law that is only happened in a social reality.

\section{Conclusion}

This paper in its progressive way tries to take the middle ground. That in fact pure legal theory is still widely practiced in the Indonesian judicial system does not mean that its application applies absolutely. Therefore, it is necessary to be given space for progressive law to color the legal system in Indonesia. Progressive law is born from a sense of dissatisfaction among the law against the theory and practice of the growing traditional law. Its adherents are criticizing the 
immensity of the "gulf" between the law practiced and the theory of law. Law is considered to fail in responding to every problem that occurs in the community. For that reason the legal sector should be more empowered so that community and nation development can be implemented or that it can be accelerated.

Harmonization of legislation in the field of government administration needs to be done. This is because there is a significant difference between the implementation of Article 2 of Law No. 5 Year 1986 jo Law No. 9 Year 2004 jo Law No. 51 Year 2009 on State Administrative Court with Article 25 paragraph (1) Law No 30 Year 2014 on Administration of Government. If a state administrative decision that still requires approval is exempted in the meaning of a state administrative decision which is the object of a state administrative dispute, then the use of discretion that has the potential to change the budget allocation that must obtain approval from superiors becomes untenable. Harmonization of legislation should be understood as an ongoing way. Progressive rules necessarily require progressive thinking that is open to all possibilities. Therefore, an underdeveloped understanding certainly will not provide the best solution to the increasingly modern problem. Criticism to become a better state of law must be addressed as a positive thing for the development of law itself.

\section{Authors bio:}

Lily Evelina Sitorus: Ministry of Law and Human Rights

Anna Erliyana: Professor of Administrative Law University of Indonesia

Yunus Husein: Dean of Jentera School of Law

\section{References}

Grey, J.H. (1979). Discretion in Administrative Law. Osgoode Hall Law Journal, 17.1.

Hoesein, Zainal Arifin. (2006). Pengujian Peraturan Perundang-undangan Menurut Konstitusi Indonesia, Studi tentang Perkembangan Pengaturan dan Pelaksanaannya oleh Mahkamah Agung RI dalam kurun waktu 1970-2003 (Disertasi Doktor). Universitas Indonesia: Jakarta.

Holzer, Marc and Kaifeng Yang. (2005). Administrative Discretion in A Turbulent Time: An Introduction. Public Administration Quarterly 29, Spring.

Indonesia. Undang-Undang Kekuasaan Kehakiman, UU No 48 Tahun 2009, Penjelasan Pasal 3.

Kelsen, Hans. (1961). General Theory of Law and State. New York: Russell \& Russell.

Mahkamah Konstitusi Republik Indonesia. (2010). Perkembangan Pengujian PerundangUndangan Di Mahkamah Konstitusi (Dari Berpikir Hukum Tekstual ke Hukum Progresif). Padang: Universitas Andalas.

Mawardi, Irvan. (1 July 2015). Konstruksi Baru tentang Keputusan Tata Usaha yang dapat diuji di PTUN. Diakses dari http://ptun-samarinda.go.id/index.php/berita/berita-terkini/25-artikel/43konstruksi-baru-tentang-keputusan-tata-usaha-negara-yang-dapat-diuji. 
Nonet, Philippe and Philip Selznick. (1978). Law and Society in Transation Toward Responsive law. New York: Harper \& Row.

Saifudin. (2006). Proses Pembentukan Undang-Undang Studi tentang Partisipasi Masyarakat dalam Proses Pembentukan UU di Era Reformasi. (Disertasi Doktor). Universitas Indonesia: Jakarta.

Tempo. (27 February 2017). Menkeu: Permasalahan Bank Diselesaikan Secara Bail-In. Diakses dari https://m.tempo.co/read/news/2016/06/17/087780758/menkeu-permasalahan-bankdiselesaikan-secara-bail-in. 